the body iron about 35 per cent. A rough calculation based on the amounts contemplated by Moran and Drummond ${ }^{2}$ suggests that the calcium intake of Orr's lowest income group may be nearly doubled by the addition of calcium to white flour. This is, of course, a very much lower increase than that used by Kletzein and Tompsett in their experiments. Certainly, this is no argument against adding calcium to the diet to combat the widespread deficiency of that element in our population; but merely correcting that fault perhaps makes it more important to combat also the deficiency of iron, which is possibly even more serious.

${ }^{1}$ Mellanby, E., Lancel, 1, 856 (1920).

Mellanby, E., Med. Res. Coun., Spec. Rep. Ser., No. 93 (1925).

'Mellanby, M., Med. Re8. Coun., Spec. Rep. Ser., No. 140 (1929).

- Templin, V. M., and Steenbock, H., Biochem. J., 27, 2061 (1933).
S Steenbock, H., Black, A., and Thomas, B. H., J. Biol. Chem., 85, 585 (1930).

'Bruce, H. M., and Callow, R. K., Biochem. J., 28, 517 (1934).

"McCance, R. A., and Widdowson, E. M., Biochem. J., 29, 2694 (1935).

${ }^{8}$ Starkenstein, E., Arch. exp. Path. Pharmak., 77, 45 (1914).

- Mottram, J. C., and Palmer, N., Cereal Chem., 14, 682 (1937).

10. Lowe, J. T., and Steenbock, H., Biochem. J., 30, 1991 (1936).

II Harrison, D. C., and Mellanby, E., Biochem. J., 33, 1660 (1939).

12 Mellanby, E., "Perspectives in Biochemistry" (Cambridge: University' Press, 1937).

${ }^{13}$ Palmer, N., and Mottram, J. C., Biochem. J., 33, 512 (1939).

"De Bruin, M., and Bouman, J., Z. Vitaminforsch., 6, 295 (1937).

16 Harris, R. S., and Bunker, J. W. M., J. Nutrit., 9, 301 (1935).

${ }^{10}$ Krieger, C. H., Bunkfeldt, R., and Steenbock, H., J. Nutrit., 20 , 7 (1940).

${ }^{17}$ Krieger, C. H., Bunkfeldt, R., and Steenbock, H., J. Nutrit., 20, $15(1940)$.

${ }^{28}$ Kreiger, C. H., and Steenbock, H., J. Nutrit., 20, 125 (1940).

18 Day, H. G., J. Nutrit., 20, 157 (1940).

so Kletzein, S. W., J. Nutritr, 19, 187 (1940).

${ }_{21}$ Tompsett, S. L., Biochem. J., 34, 961 (1940).

${ }^{22}$ Moran, T., and Drummond, J. C., NATURE, 146, 117 (1940).

\title{
A LIEBIG CENTENARY
}

$\mathrm{I}^{\mathrm{N}}$ $N$ the autumn of 1840 , just over one hundred years ago, there was published in England and Germany Liebig's famous book on "Organic Chemistry in its Applications to Agriculture and Physiology", which was destined to exert a profound influence on agricultural science and practice. It formed part of a report which, in 1837, the author had undertaken to write on the state of organic chemistry for the Chemical Section of the British Association for the Advancement of Science, and the English edition was "edited from the manuscript of the author" by Lyon Playfair, who presumably also translated it. Part 1 of this book deals with "the chemical processes in the nutrition of vegetables", and the shorter Part 2 with "the chemical processes of fermentation, decay, and putrefaction"

In treating these subjects almost entirely from the chemical aspect, Liebig followed in the wake of Humphry Davy, whom he calls "the immortal author of the Agricultural Chemistry", for Davy had there written :

"If land be unproductive, and a system of ameliorating it is to be attempted, the sure method of attaining the object is by determining the cause of the sterility, which must necessarily depend upon some defect in the constitution of the soil, which may be easily discovered by chemical analysis."

Liebig adopted this view, but went further; in the preface to the third edition of his book (1847), he wrote :

"Now that the conditions which render the soil productive and capable of affording support to plants are ascertained, it cannot well be denied that from Chemistry alone further progress in Agriculture is to be expected."

There was nothing like leather' for these distinguished chemists, and for many decades thereafter agricultural instruction in universities was undertaken as a branch of chemistry. The exaggerated importance of chemistry to agriculture at that time is quite understandable, for the science of microbiology did not exist, the nature of plant diseases and pests was virtually unknown, and no systematic attempt had been made to apply physics to agriculture. It was also due to the lack of biological knowledge that Liebig attempted to explain the phenomena of fermentation and putre. faction in terms of pure, if rather nebulous, chemistry: "whenever the way seemed long, or his heart began to fail" he would invoke such metaphysical entities as "the vital principle", vis inertice, etc., thus attempting to explain the unknown in terms of a greater unknown. The two outstanding merits of Liebig's book were that it applied, in a manner more complete than Davy and von Thaer had done, the torch of science to the unilluminated mass of facts which empirical practice had accumulated through the ages, and it laid on solid foundations the principle and practice of restoring to the soil certain nutrient elements which had been removed by previous crops.

Liebig was the first to throw light on the nature and functions of soil humus. He did not get very far, but it is doubtful if modern chemists have got very much further. He recognized that the humus 
of plant physiologists and of chemists is no single chemical individual: the soil humus he defined as "woody fibre in a state of decay". He refuted the widely prevailing view that plants draw sustenance from soil humus other than the carbon dioxide disengaged in its decay, but he held that this action proceeds only in presence of growing plants, so that bare fallowing does not deprive a soil of humus ; and that crop cultivation does not deplete the soil of humus, because this is regenerated by the organic substances excreted by plants through their roots. He laid much stress on these excretions or excrements, though he could adduce very little, if any, evidence of their existence.

According to Liebig, soil exhaustion is entirely a matter of depletion of mineral salts, chiefly those of the alkali and alkaline-earth metals, and fertility can be restored only by manuring, for example, with mineral fertilizers. He set the fashion in undertaking innumerable analyses of plant ashes, and he seemed to believe that practically every element found in the ash of a plant was necessary to its existence. Hence he devised a number of special manures containing a variety of mineral salts, some of which, such as potassium silicate and common salt, must have been redundant. These manures were a failure; farmers would have none of them. Though it is easy to criticize Liebig in the light of modern knowledge, one cannot help remarking on his failure to appreciate the nutrient reserves which nearly all soils contain in varying amounts, the availability of the added nutrients when incorporated in the soil, and the percentage recovery of them in the crop.

Foremost among Liebig's achievements in this direction was his recognition of the value of phosphatic and potassic manuring. $\mathrm{He}$ is usually, and probably correctly, regarded as the discoverer of the value of 'super' (superphosphate of lime) in the form of dissolved bones, for the preparation of which he gives a recipe in his book. It is true that Escher had already suggested the idea in 1835 , and that during 1837-39 Lawes had periormed many pot experiments with spent animal charcoal that had been treated with sulphuric acid (although there is apparently no written record of this work), but the idea could not have fructified without the work of Liebig. On the other hand, to Lawes must be ascribed priority in the preparation of superphosphate by treating mineral phosphates with sulphuric acid.

To the student of agriculture, Liebig is probably best known from his long-continued controversy with Lawes and Gilbert concerning how plants obtain their nitrogen. In the first edition of his book, Liebig wrote: "Cultivated plants receive the same quantity of nitrogen from atmosphere as trees, shrubs, and other wild plants; but this is not sufficient for the purposes of agriculture". In the fourth edition he altered the latter portion of the sentence to "and this is quite sufficient for the purposes of agriculture" (the italics are the writer's). Elsewhere, in both editions, he states that decaying nitrogenous organic matter contributes in a minor degree to the nitrogen supply of plants. Thus he shifted his ground; but his main contention was that atmospheric ammonia, originating in the decay of vegetable and animal substances, was the prime source of the nitrogen supply of plants. He was at some pains to explain how the ammonia (the amount of which in the air and rain water he over-estimated) became fixed in the soil, as both it and ammonium carbonate readily volatilize. $\mathrm{He}$ therefore postulated that minerals containing alumina, that is, clays, and iron have a great attraction for ammonia, readily combining with it and fixing it. He also asserted that humus and added charcoal act similarly. Lawes and Gilbert, in their classical experiments at Rothamsted, proved that the main source of the supply of nitrogen to plants was nitrogenous substances naturally present in, or added to, the soil. There was, of course, at that time no knowledge of nitrogen-fixing bacteria, either 'nodule' or freeliving. The result of the controversy, besides settling the main point at issue, provided the scientific basis for nitrogenous manuring.

Great as were Liebig's achievements in wedding science to practice and in establishing the value of mineral manuring, it is open to question whether his chief title to fame does not rest upon his purely chemical discoveries ; in any event his combustiontube and potash-bulbs bid fair to attain immortality. One cannot agree with the dictum of A. W. Hofmann, in his Faraday Lecture to the Chemical Society in 1875, that he and Faraday were "stars of co-equal lustre", but one can stand in admiration of his intellectual ability, of his great success in establishing the first really educational laboratory at Giessen, which attracted students from many parts of the world, and of his striking personality. As a man of science, he was at times "rash in his speculations, hasty in his conclusions, and bitter in his controversies" (Odling), but in the social sphere he seems to have possessed all the virtues. Much of his success was probably due to his personality : he possessed the deep convictions and inner fire of a Führer, not one of the ultranationalistic type, but one who, at least in scientific matters, was a cosmopolitan at heart. At the same time he would doubtless have been ready to subscribe to the dictum of Pasteur, "La science n'a pas de patrie, mais les savants en ont une".

E. H. T. 